\title{
A Petrographic Investigation of the Carboniferous Sequence from the Ibbenbüren Mine: Tracing the Origin of the Coal Mine Drainage
}

\author{
Diego Bedoya-Gonzalez ${ }^{1,2, *} \mathbb{C}$, Sylke Hilberg ${ }^{1}$, Günther Redhammer ${ }^{3}\left[\right.$ and Thomas Rinder $^{1}$ \\ 1 Department of Geography and Geology, University of Salzburg, Hellbrunner Str. 34, 5020 Salzburg, Austria; \\ sylke.hilberg@sbg.ac.at (S.H.); Thomas.rinder@sbg.ac.at (T.R.) \\ 2 Institute for Geography and Geology, University of Greifswald, Friedrich-Ludwig-Jahn Str. 17a, \\ 17487 Greifswald, Germany \\ 3 Department of Chemistry and Physics of Materials, University of Salzburg, Jakob-Haringer-Straße 2, \\ 5020 Salzburg, Austria; guenther.redhammer@sbg.ac.at \\ * Correspondence: diegoalexander.bedoyagonzalez@sbg.ac.at; Tel.: +43-662-8044-5495
}

Citation: Bedoya-Gonzalez, D.; Hilberg, S.; Redhammer, G.; Rinder, T. A Petrographic Investigation of the Carboniferous Sequence from the Ibbenbüren Mine: Tracing the Origin of the Coal Mine Drainage. Minerals 2021, 11, 483. https://doi.org/ $10.3390 / \min 11050483$

Academic Editors: Monika J. Fabiańska,

Magdalena Misz-Kennan and Justyna Ciesielczuk

Received: 31 March 2021

Accepted: 28 April 2021

Published: 30 April 2021

Publisher's Note: MDPI stays neutral with regard to jurisdictional claims in published maps and institutional affiliations.

Copyright: (c) 2021 by the authors. Licensee MDPI, Basel, Switzerland. This article is an open access article distributed under the terms and conditions of the Creative Commons Attribution (CC BY) license (https:/ / creativecommons.org/licenses/by/ $4.0 /)$.

\begin{abstract}
The mine drainage of the Ibbenbüren anthracite coal mine is characterized by exceptionally high concentrations of dissolved iron and sulfate. The elevated position of the coal field with respect to the surrounding area makes the neighboring sediments an unlikely source of these elements. Accordingly, it has been hypothesized that interaction between infiltrating rainwater and the fractured overburden is a key process governing the mine drainage chemistry. To test this hypothesis, two full-diameter core samples drilled above the discharging adit of the coal mine were investigated. The methodology combined several analytical techniques to identify and characterize traces of water-rock interaction related to both diagenesis and relatively recent weathering processes along open fractures. The coupled appearance of kaolinite-dickite-illite minerals in weathered and unweathered rock sections was clearly connected to the burial history of the Carboniferous sequence. In contrast, the formation of iron (oxide-) hydroxides together with the presence of oxidized pyrite in weathering profiles along both sides of the fractures was positively related to the geochemical footprint of the coal mine drainage. Thus, open fractures, possibly originated from mining activities, may play a significant role in the drainage chemistry, especially considering the rather poor hydraulic conditions of the overburden.
\end{abstract}

Keywords: mine drainage; Ibbenbüren anthracite coal mine; Carboniferous sequence; water-rock interaction; geochemistry

\section{Introduction}

In December 2018, hard coal mining in Germany came to its end when collieries in Ibbenbüren and Prosper Haniel ceased to operate [1-3]. However, with the end of mining activities the need for mitigation of environmental impacts still continues [4,5]. Amongst others, management of mineralized mine drainage remains a considerable challenge in many places [6-13]. The problem begins as soon as operations start, but may continue for centuries after mine closures [14-16].

Mining exposes large surfaces of coal and coal-bearing rocks to air, water and microorganisms. The oxidation of reducing agents in these layers (e.g., iron sulfides and organic matter) generates acidic conditions with exceptionally elevated concentrations of sulfate, iron and manganese ions [17]. Trace elements present in the lattice of the minerals, such as $\mathrm{Co}, \mathrm{Cu}, \mathrm{As}, \mathrm{Pb}, \mathrm{Ni}$, Se, $\mathrm{U}$ and $\mathrm{Zn}$, can also be released at levels that are harmful to aquatic and terrestrial organisms $[6,9,18,19]$. These products may be sorbed and coprecipitated by buffering minerals, resulting in their partial reduction $[18,20]$. If there are no such buffers, the referred products may be flushed from the system either rapidly or potentially long 
into the future [21]. Consequently, the drainage quality of each mine site depends on its particular structure and (hydro-) geological conditions.

Historically, the drainage of Ibbenbüren Westfield has displayed high iron (100-1000 mg/L) and sulfate $(1000-5000 \mathrm{mg} / \mathrm{L})$ contents [22,23]. Even after its closure and subsequent flooding in 1979, the mine drainage has continued to bear high loads of total dissolved solids and metals [10]. A comprehensive clarification of this mineralization, which is the highest reported for European hard coal mines, requires an approach that considers geological, hydrological and mining conditions. The Ibbenbüren Westfield represents an isolated mountain range, topographically elevated with respect to the foreland. Accordingly, it has been hypothesized that the actual chemical signature of the drainage is influenced by the interaction of percolating rainwater with sulfur-bearing rock layers above the adit. This water-rock interaction could be favored by decades of mining activities, which generate strains (i.e., deformations) derived from the redistribution, concentration, reorientation and release of stress [24]. Large vertical strains result in fracture structures that modify the hydrogeological system, increasing their hydraulic conductivity and altering the groundwater flow paths [25-29]. The percolating water can then harness these water-conducting fracture zones to interact with the rock sequence. To test this hypothesis, the present study combines several analytical techniques to characterize the Carboniferous sequence within two full-diameter core samples recovered from the Ibbenbüren Westfield. Particular attention is given to components and structures (e.g., authigenic, reactive or altered mineral phases, fractures, and morphological features) that allow identification of the mechanisms governing the chemical signature of the coal mine drainage.

\section{Site Description}

\subsection{Geological Setting}

The Ibbenbüren Carboniferous crustal block represents the largest outcrop of Paleozoic coal-bearing rocks in northwest Germany. Similar Carboniferous island-like blocks can be found in Hüggel [30] and Piesberg [31] hills, a few kilometers to the east (Figure 1). Based on tectonic studies, all three blocks have been linked to the Ruhr district, about $90 \mathrm{~km}$ to the south of Ibbenbüren. There, the Carboniferous sequence dips north under the Mesozoic rocks of the Münsterland basin, emerging in the study area due to the inversion of the Osning fault in the Upper Cretaceous [32,33]. At that time, the block was subject to compressive strength produced by dextral movements. This generated a crustal uplifting of about $2 \mathrm{~km}$ compared to the Triassic and Jurassic foreland, currently under the Quaternary deposits [32]. Consistently, the Carboniferous sequence developed an island-like appearance, being limited on all its sides by marginal faults that follow the NNW-SSE Osning thrust axis (Figure 1) [34].

Antithetic faults created during the tectonic inversion also divide the Carboniferous block into 2 NNE-SSW striking horst structures separated by the Bockradener graben [23]. Horst structures were named East- and Westfield for mining purposes (Figure 1). An additional boundary between the Westfield and Bockradener graben was also defined at the Pommer-Esche fault, where the rock sequence exhibits vertical displacements from 210 to 500 meters [34]. Finally, several local faults further segment the Westfield into small blocks, promoting the infiltration of meteoric water (Figure 1).

\subsection{Stratigraphy}

Rock layers in the study area were deposited during the higher Westphalian $C$ and lower Westphalian D stages [30,37]. The sequence is composed of an alternating pattern of sandstone and conglomerate layers (approx. 80\%), with few mudstone levels (20\%) wherein 81 coal seams are included [34]. On top of this, thin Quaternary sediments sparsely cover the sequence, as well as two localized waste rock deposits, which do not extend more than $0.5 \mathrm{~km}^{2}$. Because of the low dip angle $\left(<10^{\circ}\right)$ and fairly constant nature of the rocks, coal seams offer good reference levels when comparing the stratigraphic sequence 
at various locations into the field [23]. However, parallelization between areas is often uncertain due to strong facies changes at large-scales.

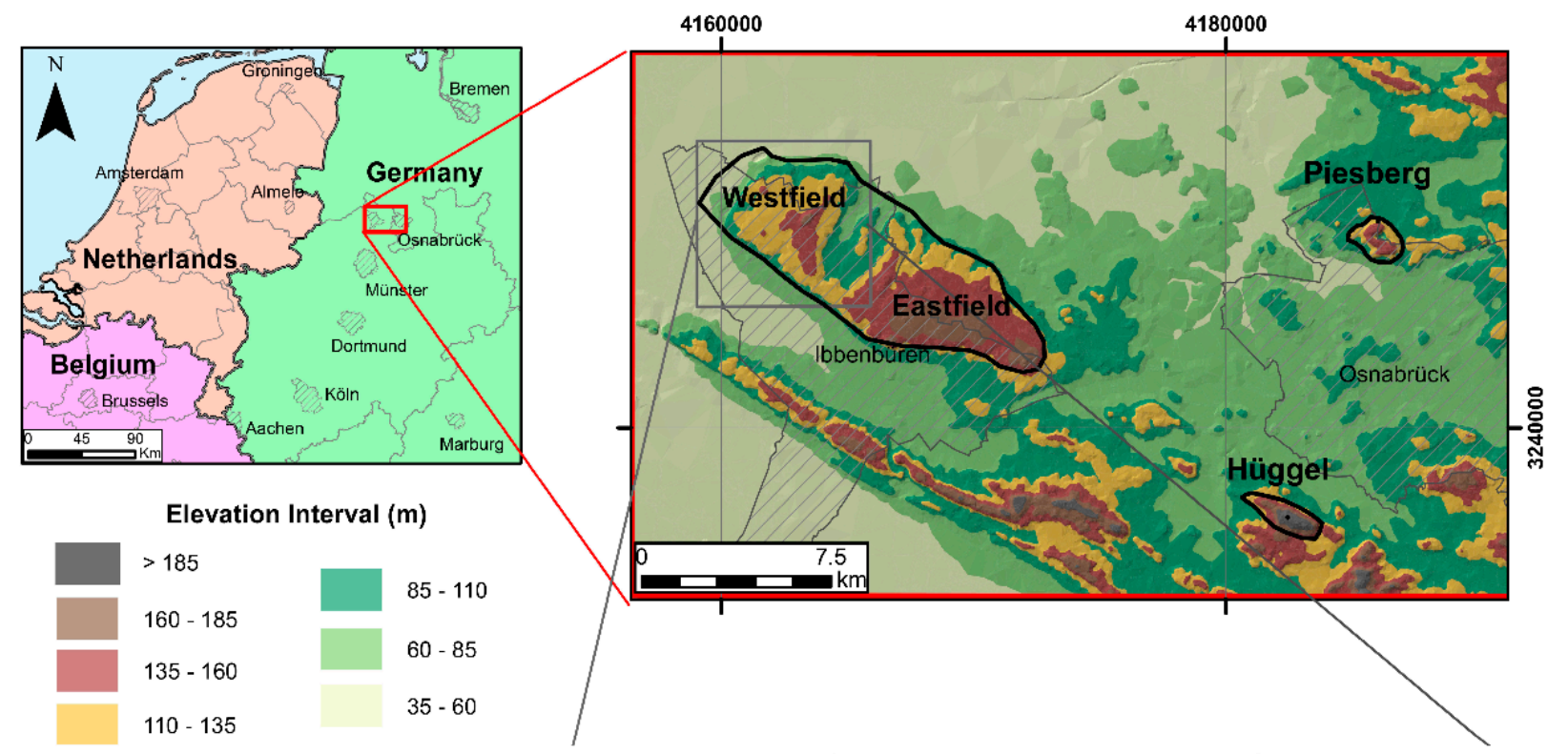

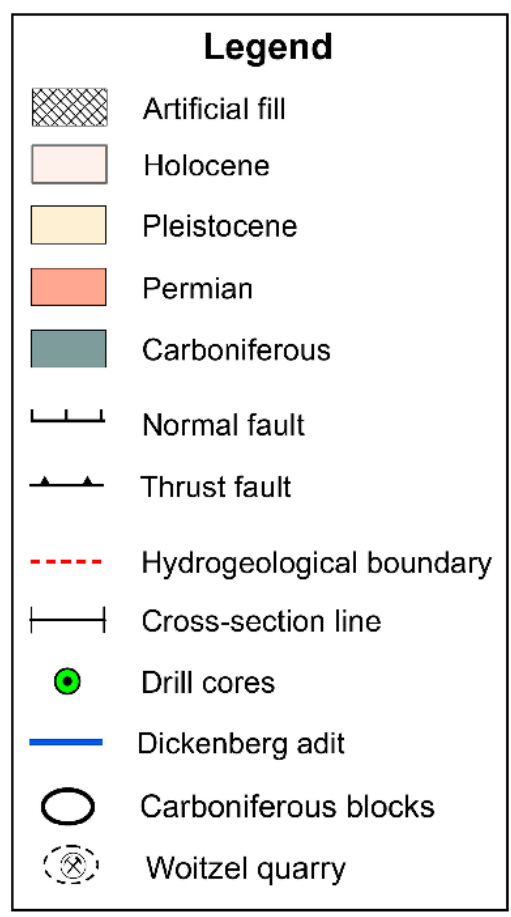

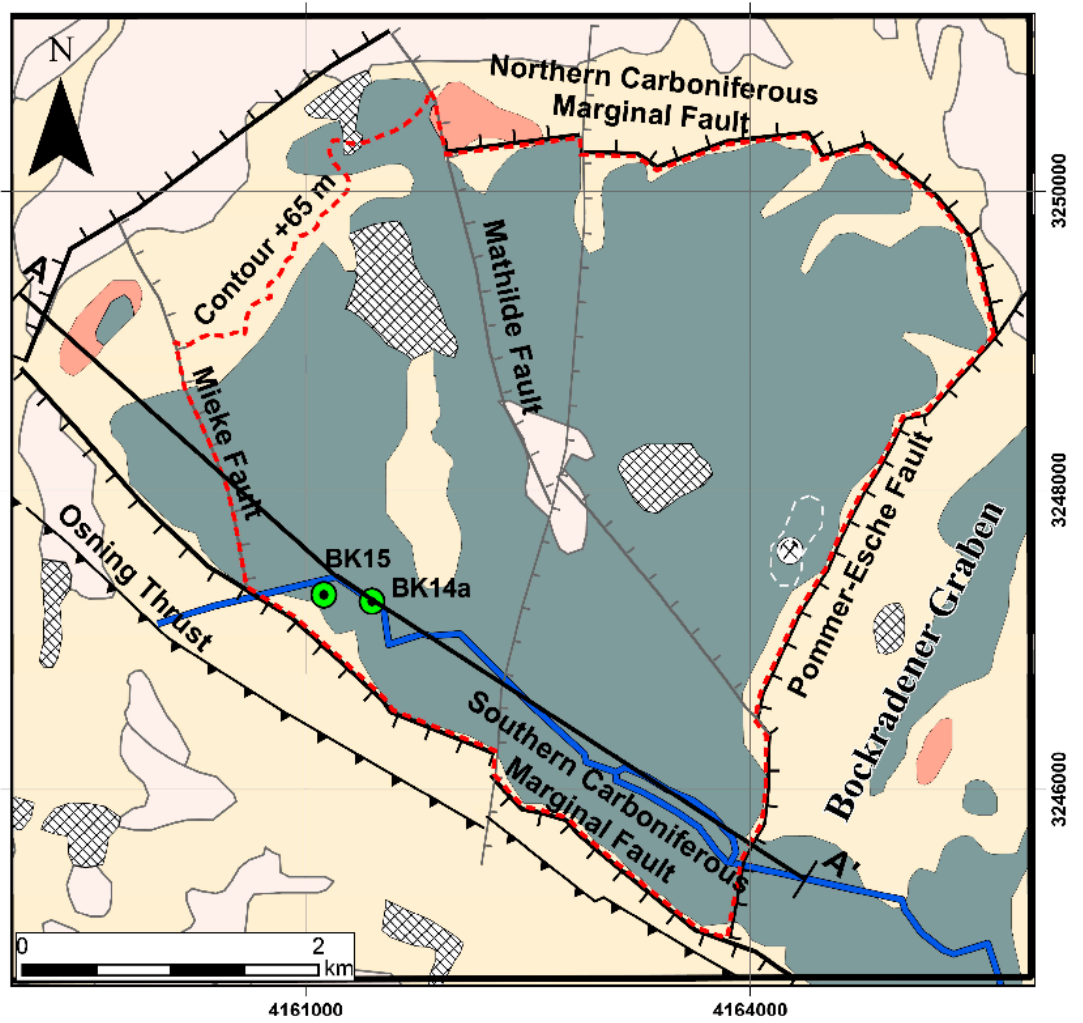

Figure 1. Geographic and geological maps of the studied area. The polygons enclosed by the thick black line in the digital elevation image additionally illustrate the location of the other two Carboniferous blocks in the surrounding area. The A- $\mathrm{A}^{\prime}$ line denotes the position of the cross-section in Figure 2. Modified after [10,35,36].

\subsection{Hydrogeological Conditions}

Mining in the Westfield stopped in June 1979, with excavations as deep as $600 \mathrm{~m}$ below the ground level [22]. After closure, the dewatering system was progressively shut down, allowing groundwater to bounce back. As a result, the area was flooded under control up to an elevation of around $65 \mathrm{~m}$ a.s.l., where the groundwater reaches the Dickenberg adit 
(Figure 2) [38]. Nowadays, this level is still regulated by direct connections between the adit and the Dickenberg coal seam [22].

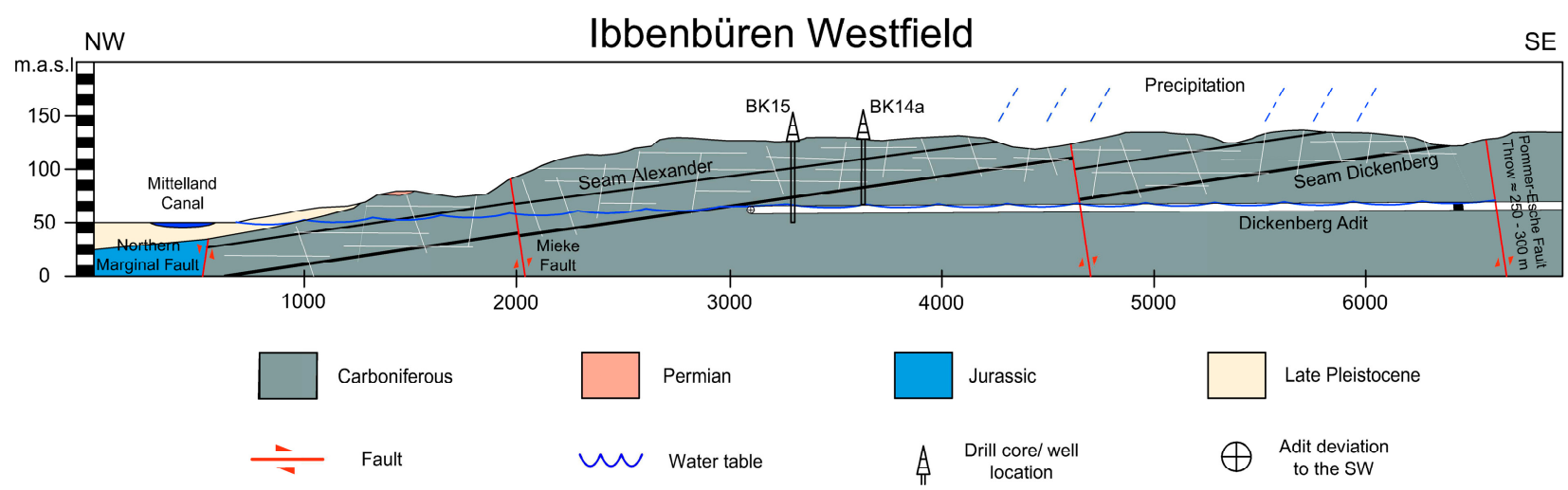

Figure 2. Geological cross-section of the Ibbenbüren Westfield (cross-section line A-A' in Figure 1). The cross-section is vertically exaggerated $5 x$ to better detail the shallow overburden structure and current hydrogeological situation. Modified after [39].

As the phreatic level of the former coalfield is above the foreland surface $(<55 \mathrm{~m}$ a.s.l.), precipitation turns into the unique source of groundwater recharge. The thin and sparse Quaternary sediments offer neither storage capacity nor resistance for meteoric water to percolate. Likewise, percolation may be promoted by water-conducting fracture zones as Lotze et al. [23] and Bässler [34] suggested. Both authors observed a direct correlation between seasonal precipitation events and the amount of discharged mine water. Additionally, both authors described a sharp drop in the groundwater table for the whole Westfield when mining was active. The development of a continuous cone of depression rules out the presence of a free aquifer on top of the sequence while confirming a direct connection between the surface and underground works. The actual discharge of the adit, therefore, depends on the amount of meteoric water that percolates through the overburden enclosed by the northern and southern Carboniferous marginal faults, Mieke Fault and PommerEsche Fault. Furthermore, groundwater can only be extracted from areas higher than the Dickenberg adit, turning the terrain contour $+65 \mathrm{~m}$ into an additional hydrogeological limit (Figure 1).

\section{Materials and Methods}

Full-diameter rock samples (i.e., 4 inches diameter) from two drill cores were evaluated in this study. The samples were obtained from a drilling campaign for the construction of a new drainage adit in Ibbenbüren, where boreholesBK14a and BK15 were the only ones drilled on the Westfield. In total, more than $130 \mathrm{~m}$ of rock samples, with an approximately stratigraphic representation of $80 \mathrm{~m}$, were recovered (Figure 3). From these, 22 intervals were picked for further investigation including mineralogy, rock structures and alteration zones. The selected intervals included at least two samples of each lithology identified on the drill cores. These were chosen with a depth spacing as regular as possible to homogeneously cover the whole sequence. Additionally, intervals with the presence of reactive, unstable or altered mineral phases (e.g., pyrite, carbonates and (oxide-) hydroxides) as well as with permeable features such as fractures were also selected.

Detailed petrographic characterization was carried out on 22 thin sections of the selected intervals. Descriptions were performed with a LEITZ laborlux 12 polarized microscope with magnifications between 2.5 and $40 \times$. Although all slides were carefully examined, only six sections of the most frequent rock intervals with both altered and pristine zones were selected to perform detailed point-counting analysis, as described by the Gazzi-Dickinson method (e.g., see [40]). For each thin section, 300 points were counted using a maximum of $1 \mathrm{~mm}$ grid spacing covering the entire slide. This amount 
of counts yielded statistically reliable values for all parameters, reasserting the textural and compositional classification of overburden rocks. Grain size and sorting analysis was performed by measuring the long axis of at least 100 grains per thin section. Petrographic descriptions were complemented with the analysis of two thin sections under a Zeiss Ultra Plus 55 field emission scanning electron microscope (SEM). Measurements were carried out with an accelerating voltage of $15 \mathrm{kV}$ and a working distance of approximately $10 \mathrm{~mm}$. The dispersive X-ray spectrometer system mounted in the SEM was further used to identify unknown accessories and clay minerals.

Drill core BK14a
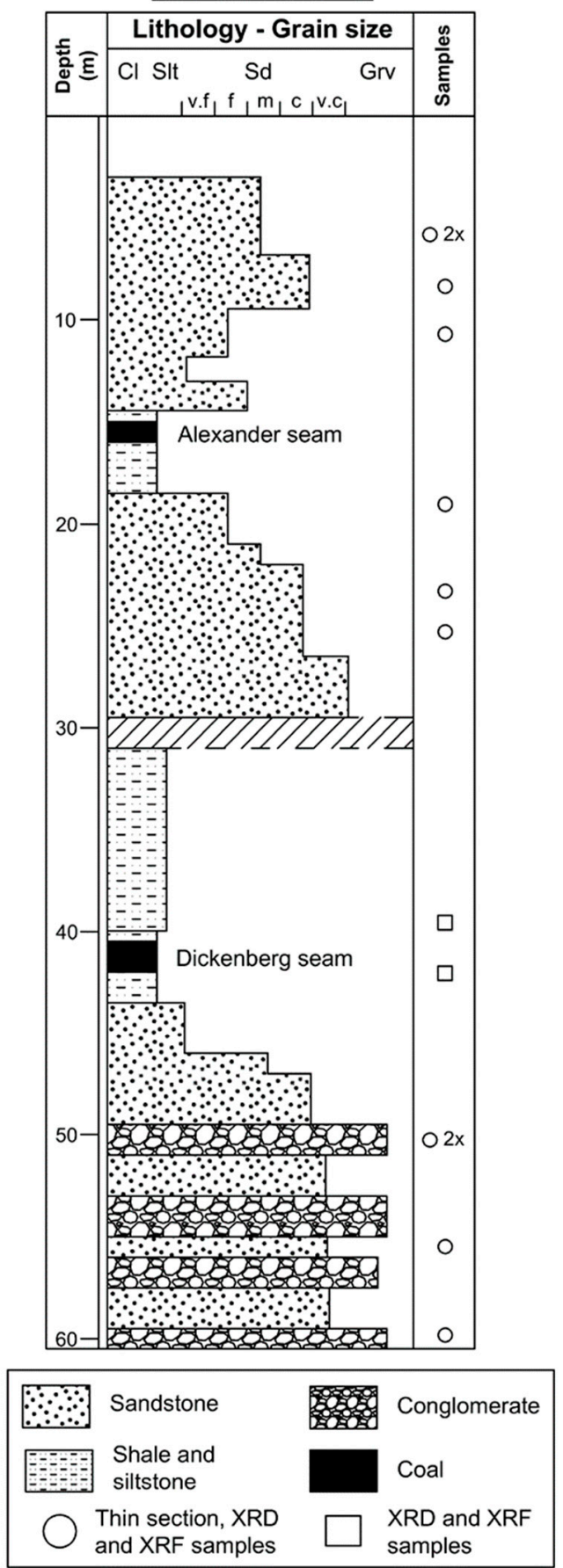

Drill core BK15

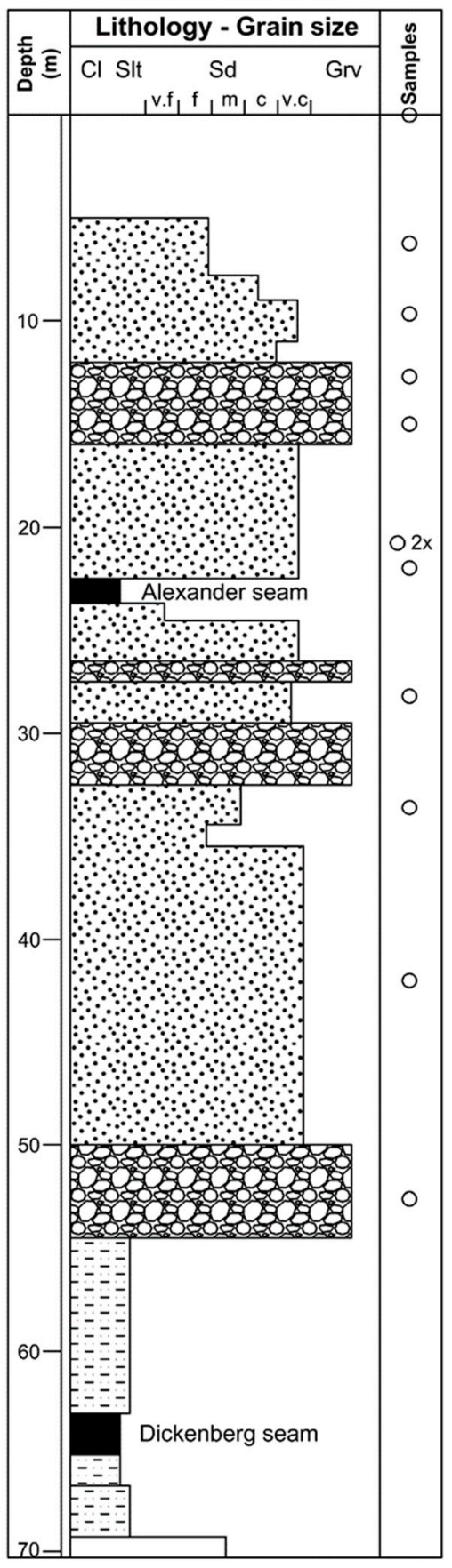

Figure 3. Stratigraphic columns of the two core-samples recovered in the area. The sketch includes lithology and location of the samples analyzed in this paper. $\mathrm{Cl}=$ clay, $\mathrm{Slt}=$ silt, $\mathrm{Sd}=$ sand (v.f: very fine, f: fine, m: medium, c: coarse, v.c.: very coarse), Grv = gravel. 
Mineralogical composition of the rocks was determined by powder X-ray diffraction (PXRD) on 34 samples. The measurements were collected in coupled Theta-Theta mode on a Bruker D8 Advance diffractometer (Bruker AXS, Karlsruhe, Germany), being equipped with a fast-solid-state Lynxeye detector and an automatic sample changer. Data acquisition was performed using $\mathrm{CuK} \alpha 1,2$ radiation between $10^{\circ}$ and $90^{\circ} 2 \mathrm{Theta}$, with a step size of $0.015^{\circ}$, integration time of $1 \mathrm{~s}$, with the divergence slit and the anti-scatter-slits opened at $0.3^{\circ}$ and $4^{\circ}$, respectively. A primary and secondary side $2.5^{\circ}$ Soller slit was used to minimize axial divergence, and the detector window opening angle was chosen as $2.93^{\circ}$.

Finally, the elemental composition of selected weathered and unweathered rock samples $(n=34)$ was analyzed with "S4 Pioneer" X-ray Fluorescence microscopy (Bruker AXS). This device is equipped with a $4 \mathrm{~kW}$ X-ray tube, whereby the main elements were measured with reduced power. The counting times were chosen in such a way that the double standard deviation for $\mathrm{SiO}_{2}$ and $\mathrm{Al}_{2} \mathrm{O}_{3}$ was below $1 \%$ (relative) and below $5 \%$ (relative) for those elements that contained 1-10\%. At low concentrations ( $<10 \mathrm{ppm})$ the measurement error is typically 1-3 ppm. At concentrations around $1000 \mathrm{ppm}$, the errors are maximum $50 \mathrm{ppm}$, but with many trace elements, they are significantly lower.

\section{Results}

\subsection{Core Logging}

\subsubsection{Lithology}

The most frequent lithology in the drill cores corresponds to greyish hard sandstone layers, medium-to-coarse-grained and moderately sorted. Layers are homogeneously composed of quartz, sedimentary lithic fragments (mostly chert, mudstones and coal), muscovite, and variable pyrite amounts. Rocks do not present cement, but a clayey matrix produces a dense hard packing with apparent low porosity (Figure 3). Sedimentary features include massive and cross-bedding structures, with local variations to conglomeratic lenses. Some intervals show reddish tones associated with precipitation of iron (oxide-) hydroxides near fracture structures.

Interspersed with the sandstones, clast-supported pebble conglomerates appear in the sequence (Figure 3). These are massive and poorly sorted rocks, with normal gradation to very coarse-grained sandstones of similar composition as described above. Lastly, few levels of dark-gray mudstone and remnants of two coal seams were found in both drill cores (Figure 3). According to a personal communication of the RAG Company, these two coal samples belong to Alexander and Dickenberg seams. By taking them as guides, a significant textural fluctuation is observed laterally (Figure 3). For instance, in between the two coal seams, lithology varies from fine-to-medium-grained on the core BK14a to very-coarse and conglomeratic on the core BK15.

\subsubsection{Joints and Fractures}

Rock breakups were grouped into joints and fractures according to their influence on the integrity and alteration state of the samples. Other parameters such as strike, inclination or dip direction were not evaluated due to lack of on-site information and sample orientation.

Joints correspond to short and relatively planar cracks, easily traceable by their narrow alteration zones. They display millimeter-scale tensional offsets and reddish-brown altered fringes of up to $0.5 \mathrm{~cm}$ at each side of their planes (Figure $4 \mathrm{~b}$ ). Secondary iron hydroxides commonly close the open spaces, cementing the divided fragments (Figure 4a). However, no other sealing element associated with the mineralogical composition of the rock, such as quartz veins or clay smears, was observed.

Fractures, on the other hand, are open structures that segment the core samples into two or more pieces. Weathering fronts with precipitated iron (oxide-) hydroxides are consistently related to them, changing the rocks' optical properties according to their distance from the fractures (Figure 4c). Rock sections close to fracture planes develop more intense and hard reddish-brown crusts in comparison with further areas. In general, these 
alteration zones extend for several centimeters on both sides of the planes, comprising even the whole core interval in coarser lithologies (Figure $4 \mathrm{c}, \mathrm{d}$, respectively).

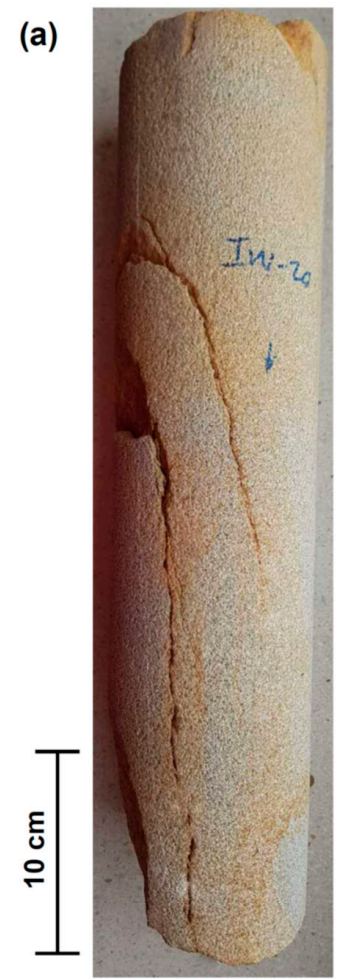

(b)

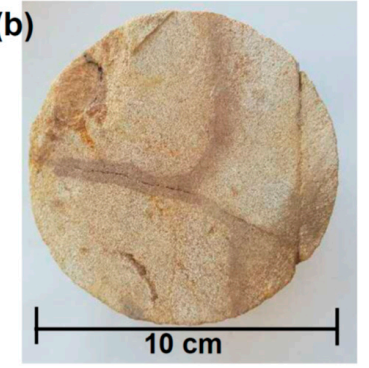

(c)

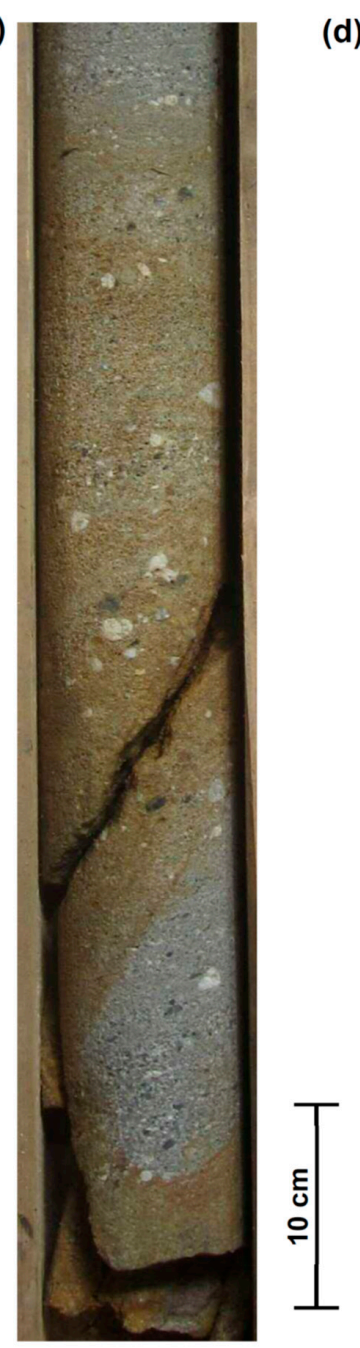

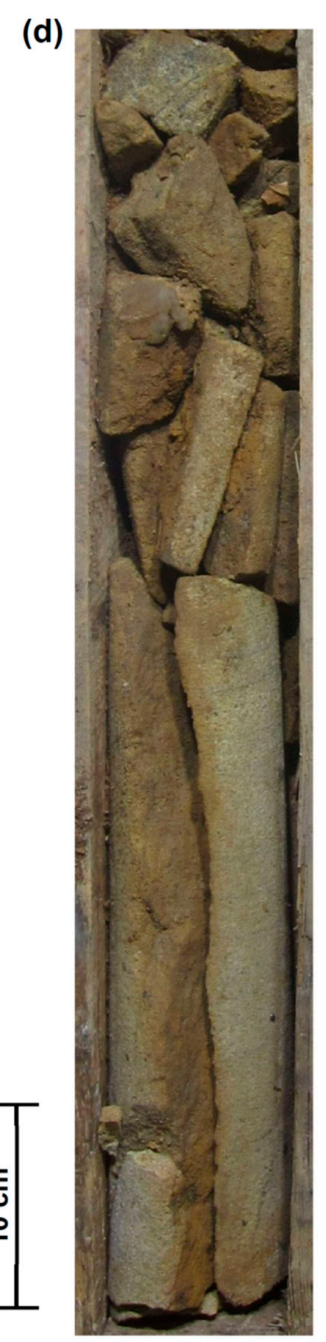

Figure 4. Types of breakups encountered during the core logging. (a) Longitudinal and (b) crosssectional images of joint networks, displaying limited alteration zones. In both sections iron (oxide-) hydroxides hold the rock pieces together hindering fluid flow. (c) Sub-vertical fracture showing clear influence in the weathering state of the sandstone interval. (d) Cracked sandstone interval with a sub-vertical fracture potentially associated with the exploitation of the Dickenberg coal seam, $4 \mathrm{~m}$ below it (this structure can be tracked on the core BK15 for approx. $5 \mathrm{~m}$ ).

\subsection{Petrography}

Sandstones display high proportions of detrital quartz, with little evidence of overgrowth or sutured contacts. Most of the lithic fragments correspond to chert and ductile mudstones partially altered to sericite (Figure 5a). Additionally, lenses and high amounts of coal fragments appear in several layers, some of which exhibit oxidation signs on the surrounding matrix (Figure 5b). Detrital muscovite and ductile lithics are frequently affected by compaction, being incorporated into the primary pore spaces as pseudomatrix (Figure 5a). Unaltered feldspars are extremely rare, although their initial presence is interpreted from the development of pseudohexagonal stacks of kaolinite-group minerals. Pyrite occurs as clusters of very fine sand and silt crystals (i.e., microcrystalline pyrite) usually associated with sedimentary lithic fragments and rarely as frame macrocrystals (Figure 5c). Finally, iron (oxide-) hydroxides are found coating and covering lithoclast surfaces in fractured core intervals (Figure $5 \mathrm{~d}$ ). 

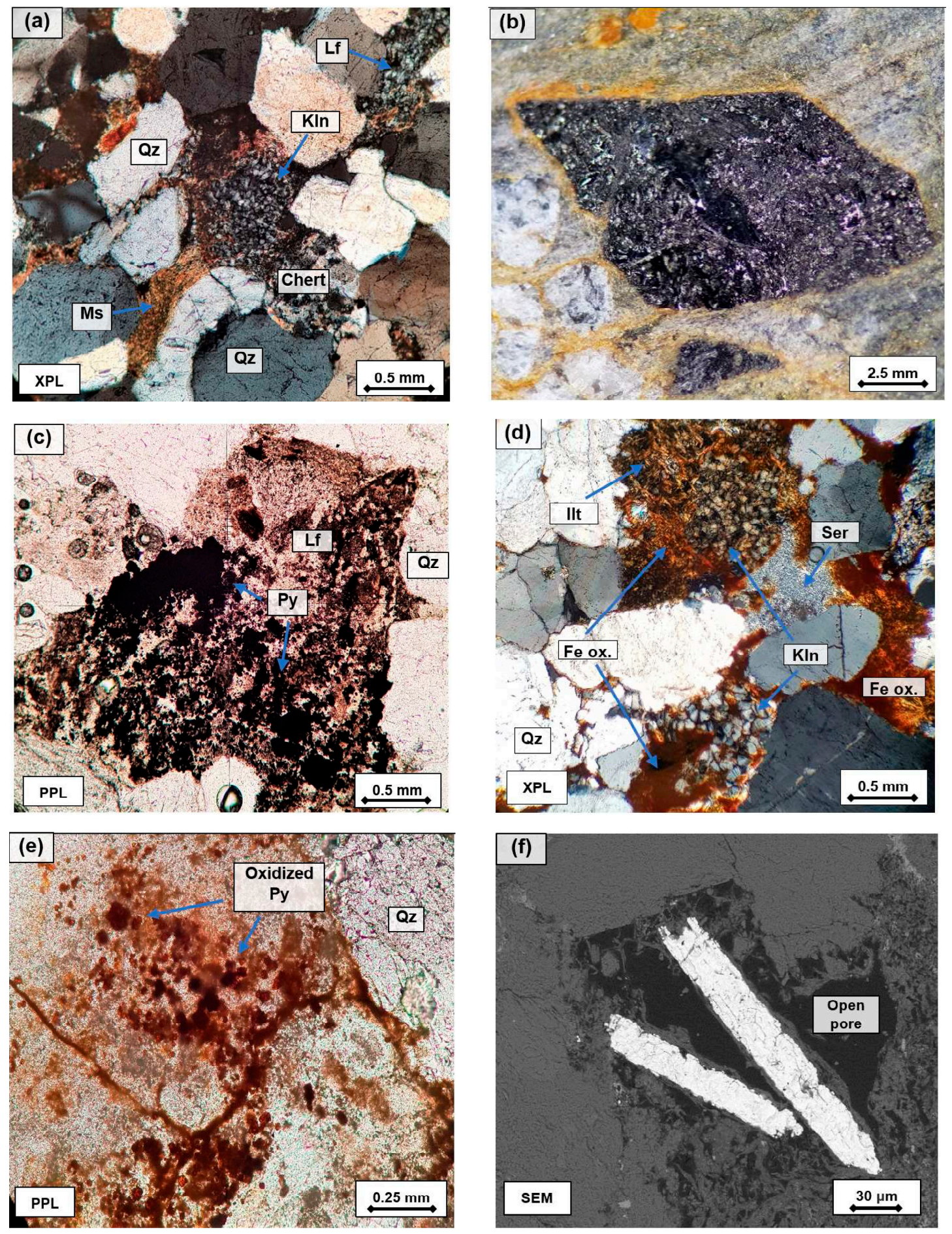

Figure 5. Photomicrographs of the main components found in the rock sequence. (a) Plastic lithic fragments, muscovite flakes and booklet crystals of kaolinite-group minerals squeezed among quartz and chert grains. The authigenic origin of the kaolinite-group minerals is interpreted from the pseudo-hexagonal form of the pore space. (b) Oxidation of a coal lithic fragment within conglomeratic sandstone interval. (c) Unaltered cluster of microcrystalline pyrite associated with a sedimentary lithic fragment. (d) Weathered thin section with iron (oxide-) hydroxides precipitating around and on the matrix and rock components. (e) Weathered cluster of microcrystalline pyrite completely transformed to iron (oxide-) hydroxide (holo-pseudomorph). (f) SEM image of prismatic barite crystals in a pore space. Lf = lithic fragment, Ms = muscovite, $\mathrm{Kln}=$ kaolinite-group minerals, $\mathrm{Qz}=$ quartz, Py = pyrite, Ilt = illite, Ser = sericite, Fe ox. = iron (oxide-) hydroxides, $\mathrm{PPL}=$ plane polarized light, $\mathrm{XPL}=$ cross polarized light, $\mathrm{SEM}=$ scanning electron microscope. 
Based on point counting, sandstones can be classified as medium-grained sublithic arenites with some variations to coarse-grained lithic arenites. Both lithologies present granoblastic texture with gradational and parallel-oriented structures. Samples exhibit textural maturity, expressed in moderately sorted frameworks, with sub-rounded and moderate spherical grains. In general, normalized mineralogical compositions display $58 \%$ mono- and polycrystalline quartz grains, $22 \%$ lithic fragments and $15 \%$ authigenic clay minerals (kaolinite-group minerals and illite). Minor constituents include 3\% muscovite, $<2 \%$ alkali feldspar and 5\% microcrystalline pyrite. However, this latter figure may have been overestimated due to the dark opaque nature of a range of thin section components (mudstone, coal particles and iron oxides). Within weathered rock zones, up to $5 \%$ of iron (oxide-) hydroxides are additionally present. These appear as a massive solid phase, darkening the frame and clay matrix minerals of the samples (Figure 5d). Pellicular rims of (oxide-) hydroxides can also be spotted around pyrite and coal particles, evolving in some cases into full crystal replacement (holo-pseudomorphism-Figure 5e). Lastly, SEM and EDS images reveal trace quantities of barite and heavy clay-size particles, enriched in strontium, lead and rare earth elements (i.e., lanthanum, cerium and neodymium). These were rarely encountered in the primary porosity of the rock, alongside the clayey matrix (Figure 5f).

Under the XRD, both weathered and unweathered rocks did not show significant mineralogical differences. As an exception, pyrite was only identified in selected unweathered samples. Diagnostic peaks of kaolinite group minerals reveal the presence of both kaolinite and dickite in the samples (Figure 6).

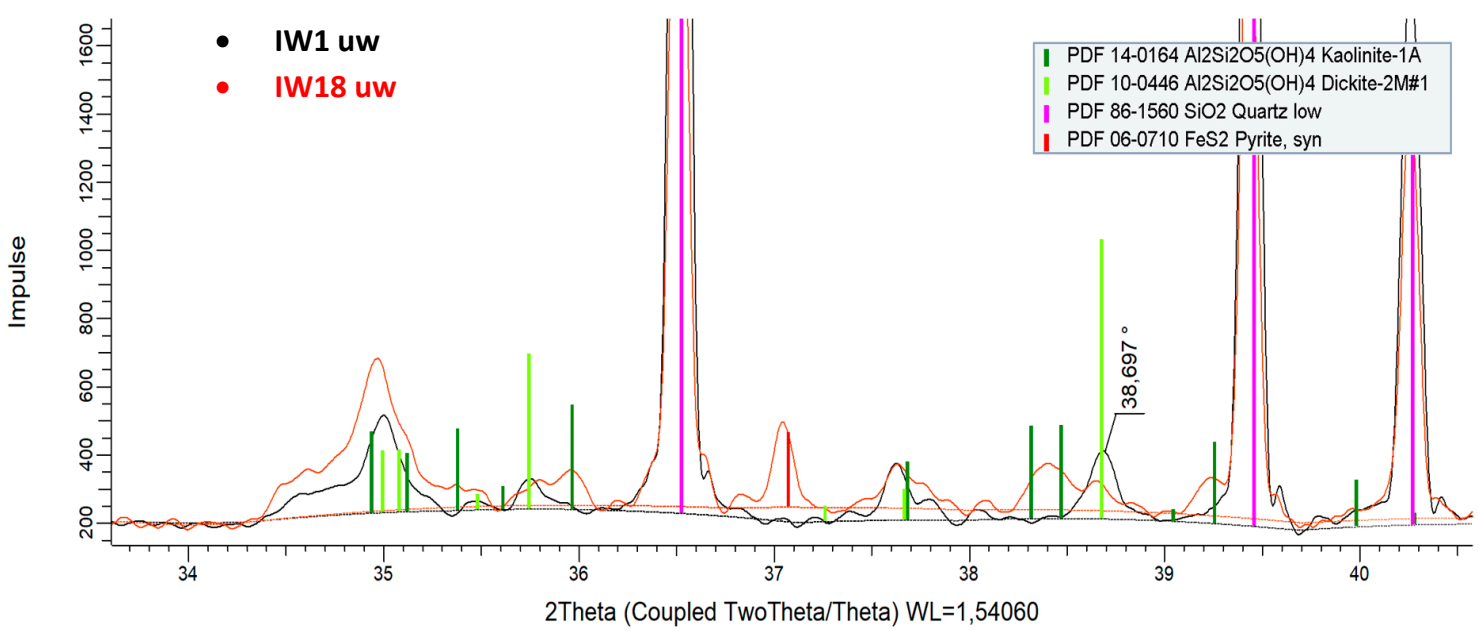

Figure 6. Diagnostic peaks of quartz, pyrite, kaolinite and dickite for samples IW1 uw and IW18 uw.

\subsubsection{Rock Matrix}

The matrix is predominantly composed of lithic fragments (pseudomatrix) and authigenic clayey minerals. The pseudomatrix corresponds to ductile mudstone and fine-grained lithic fragments, with significant alteration to sericite (Figure 7a). The criteria for classifying them as pseudomatrix implies that individual fragments are hardly distinguishable, but their deformation is still visible through flow structures (e.g., see [41]). Other lithics like coal and chert remain undeformed taking part of the rocks' frame.

Most of the clayey matrix occurs as stacks of face-to-face plates and booklet crystals of kaolinite-group minerals. The pseudohexagonal shape of these aggregates suggests that they were formed from the alteration process of detrital feldspars. Additionally, elongate, filamentous and hairy crystals of illite are also observed on the top and edges of these minerals. The bright interference colors on plain-colored booklet-shaped crystals show their illitization to some extent. To rule out illite pseudomorphism and, therefore, complete replacement of the kaolinite-group minerals, the coexistence of both minerals 
was investigated through SEM and EDS. Results validate the partial illitization of the sample, confirming the consistency between the characteristic habit of the minerals and their chemical composition (Figure $7 \mathrm{~b}-\mathrm{d}$ ).
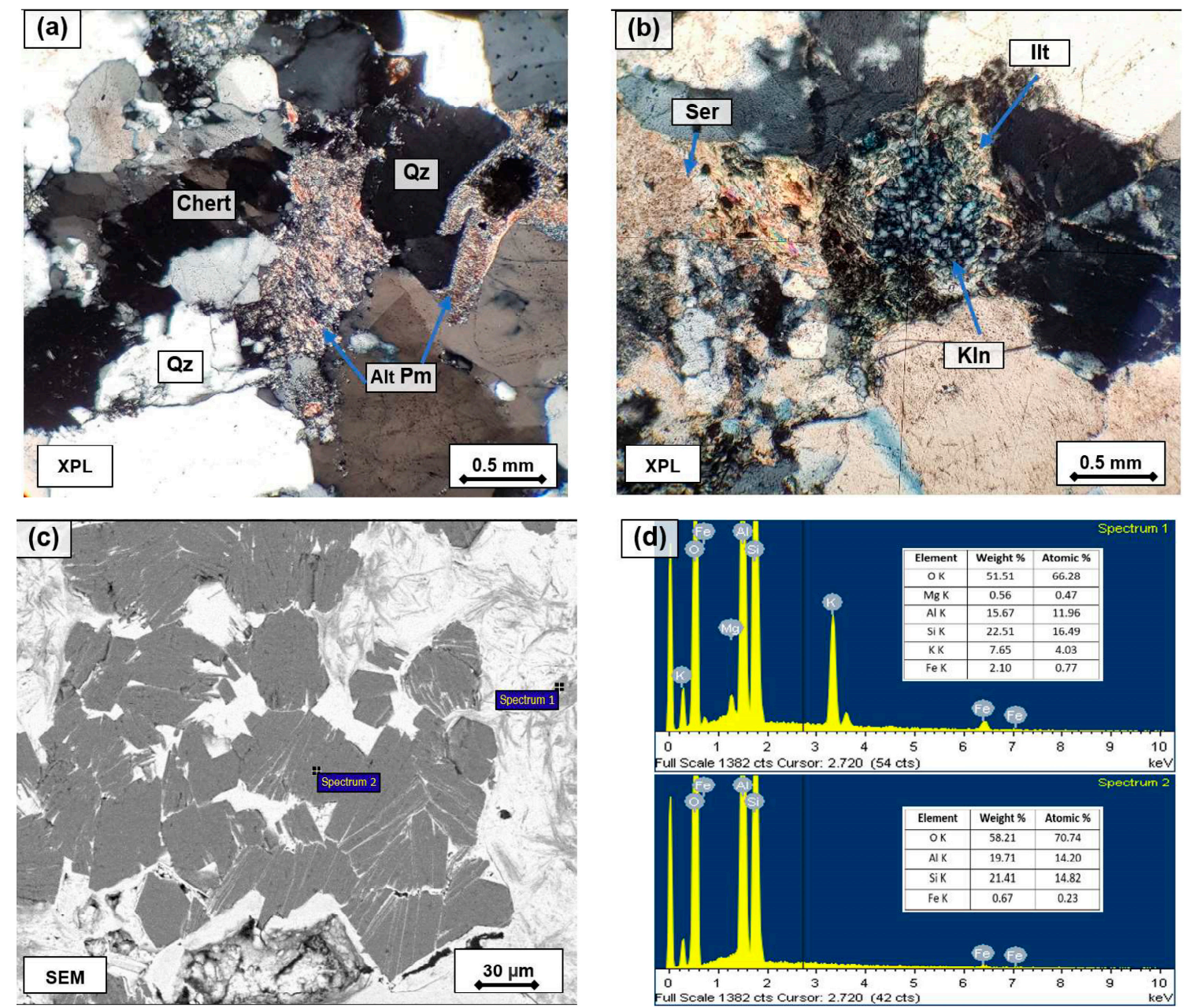

Figure 7. Rock matrix components. (a) Altered pseudomatrix squeezed among quartz and chert grains. (b) Authigenic clayey matrix found in the sample. Illite fibers stand out from their bright interference colors around the loose aggregates of kaolinite-group minerals, while sericite is frequently observed on the surface of sedimentary lithic fragments. (c,d) Illite and kaolinite-group minerals with their respective EDS signals. Alt Pm = altered pseudomatrix, Qz $=$ quartz, Kln $=$ kaolinitegroup minerals, $\mathrm{Ilt}=$ illite, $\mathrm{Ser}=$ sericite, $\mathrm{PPL}=$ plane polarized light, $\mathrm{XPL}=$ cross polarized light, $\mathrm{SEM}=\mathrm{scanning}$ electron microscope.

\subsubsection{Porosity and Permeability}

The visual porosity of the analyzed thin sections is between 8 and $11 \%$. Core samples are characterized by moderately sorted sediments and straight-line contacts, with few sutured or point junctions among the sub-rounded grains (Figure 8a). This type of arrangement creates intergranular pore spaces that can be either free or matrix-filled. In the area, most of the samples exhibit a significant percentage of clayey matrix $(15 \%)$ that, together with the sorting grade of the rocks, results in the rather low porosity. Moreover, primary porosity is reduced by the formation of pseudomatrix, which represents around $10 \%$ of the total rock volume.

In addition to the counted primary porosity, secondary microporosity was also identified within the stack of booklet crystals of the kaolinite-group minerals. This feature, widely discussed in petroleum engineering papers (e.g., see [42]), was highlighted by the blue-dye epoxy used in the samples (Figure 8b). Although no percentage was determined, 
it may contribute largely to the total porosity considering the extensive development of kaolinite-group minerals in the rocks. This idea is supported by Wüstefeld et al. [31] who performed visual and helium pycnometry measurements on sandstone outcrops in Piesberg. Discrepancies of about $4 \%$ between both techniques were attributed to the development of microporosity in authigenic clay minerals, only detectable by helium pycnometry. As the two rock sequences are comparable in terms of age, composition and burial history, a similar effect in the studied samples can be assumed (i.e., porosity values around $15 \%$ ).
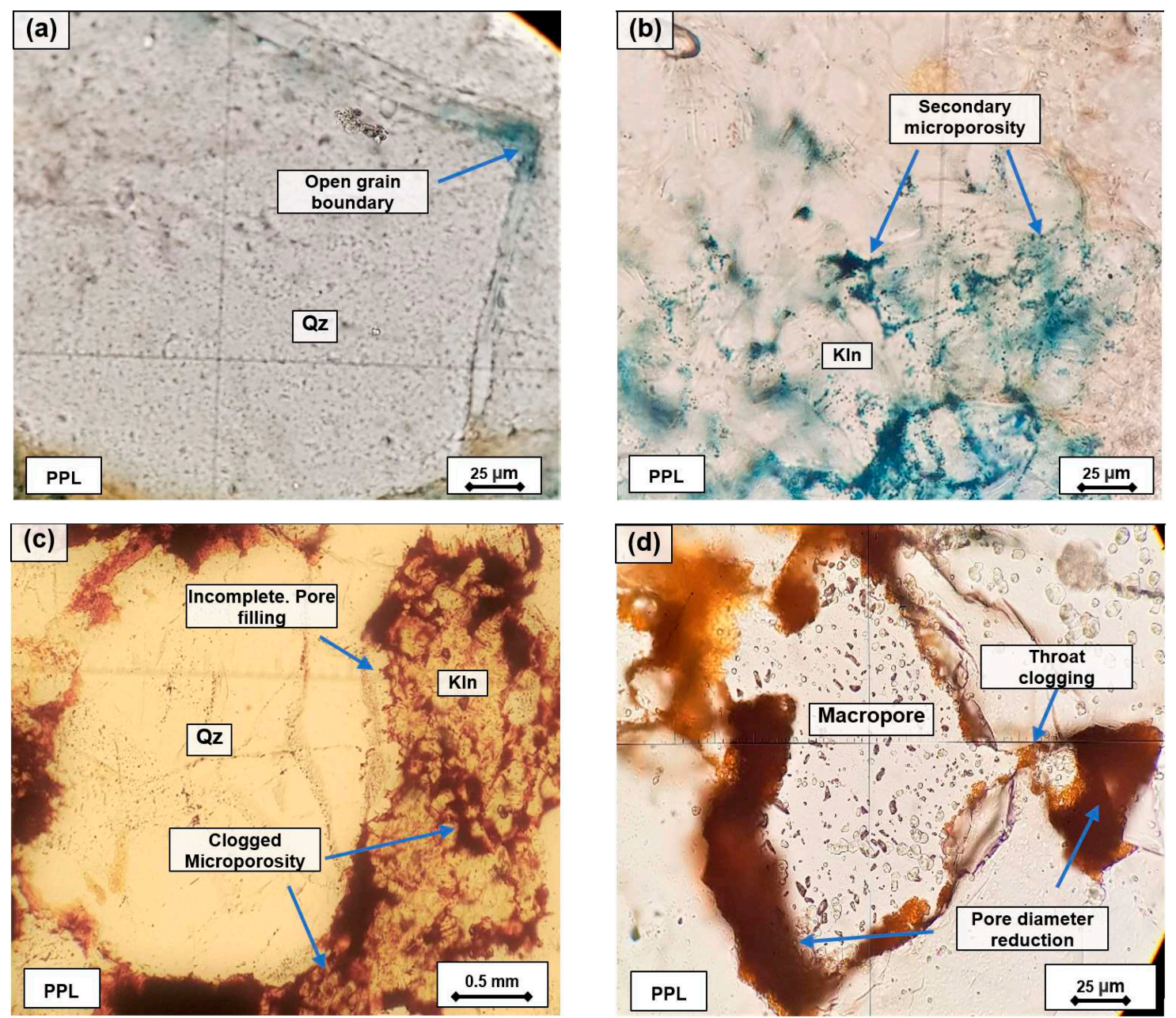

Figure 8. Overview of the rock porosity. (a) Open straight-line contact between two quartz grains developing primary porosity. (b) Secondary microporosity highlighted by the speckled, pale blue color of the resin. (c) Thin section of a weathered interval displaying clogging of primary and secondary microporosity. (d) Iron (oxide-) hydroxides pore-lining, reducing and blocking the connection between pore spaces. Qz = quartz, Kln = kaolinite-group minerals, $\mathrm{PPL}=$ plane polarized light.

Finally, low permeability values are expected for the studied overburden. Reduction of the rock porosity by ductile fragments tends to disconnect the free pathways of the bedrocks. Likewise, iron (oxide-) hydroxides frequently precipitate on the clayey minerals and pore throats, potentially reducing the connection between adjacent free spaces (Figure 8c,d).

\subsection{Elemental Rock Composition}

The chemical composition of the selected rock samples is shown in Table S1 of the supplementary files. Generally, the elemental composition of both weathered and unweathered sections resembles the results from the petrological investigation. Iron content 
increases in the reddish weathered rock zones with respect to the unweathered zones (Figure 9a). In contrast, aluminium content does not vary in between sections, indicating only minor importance of secondary Al-bearing (oxide-) hydroxides in the weathered rock zones. In addition, both alkaline and earth alkaline elements are correlated to $\mathrm{Al}$ content, indicating their siliciclastic origin. Potassium and magnesium do not vary significantly between weathered and unweathered rock zones (Figure $9 b, c)$. Nickel, zinc and, to a lesser extent, lead (Figure $9 \mathrm{~d}-\mathrm{f}$ ) are correlated with secondary iron phases, indicating co-precipitation and sorption. In principle, sulfide minerals in the Carboniferous sequence are potential sources of those metals. Moreover, it has been suggested that they migrated vertically into the Carboniferous sandstones when the area was still covered by shale, halite, limestone and conglomerate layers of Permian (Zechstein) age [23]. However, the recent influence of these Zechstein remnants that were dragged up by the south and north marginal faults has been discarded by isotopic studies carried out by Rinder et al. [10] in the Ibbenbüren Eastfield.
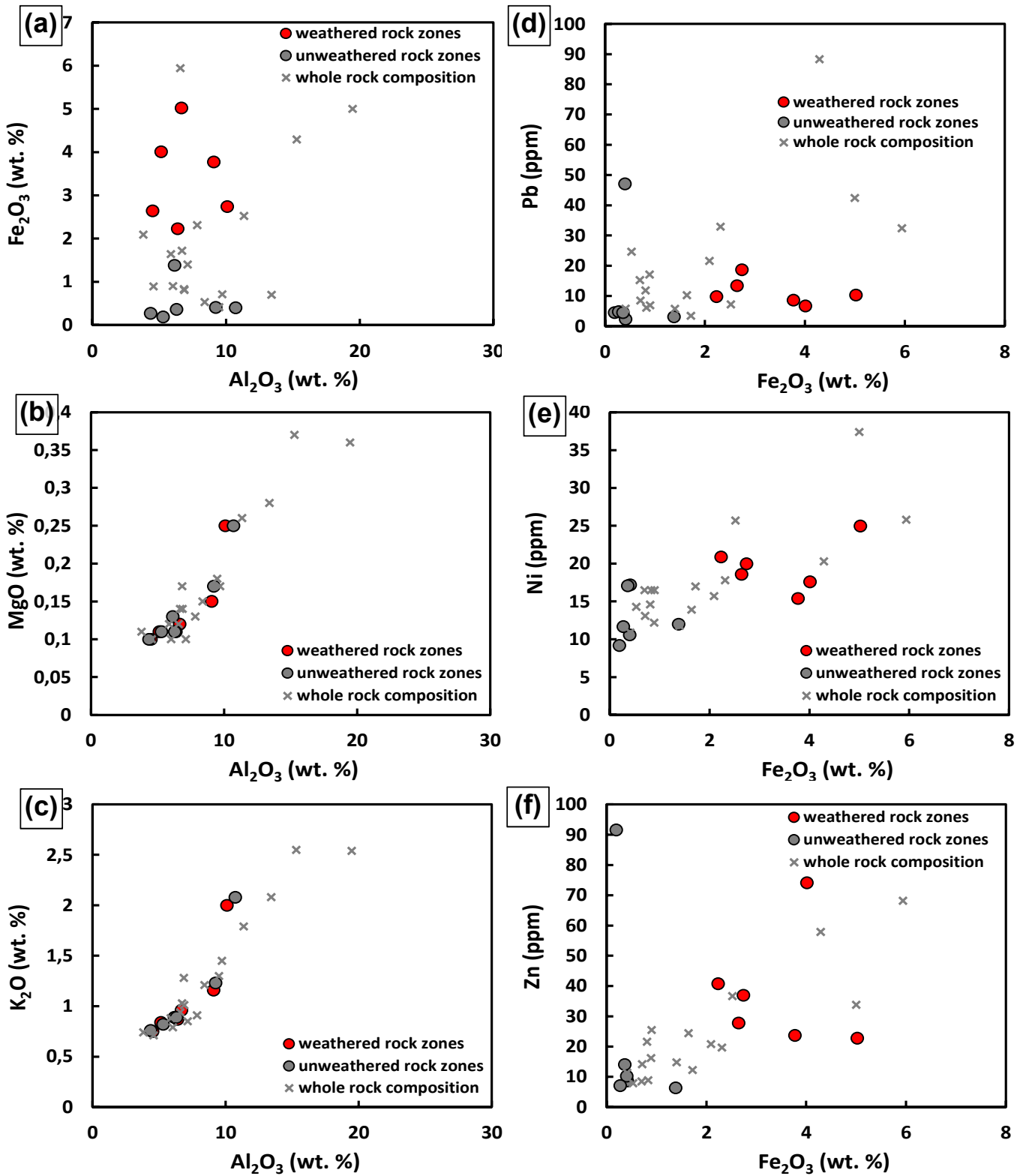

Figure 9. Elemental composition of analyzed rock samples. Potassium and magnesium do not vary between weathered and unweathered zones, indicating low influence of water-rock interaction on aluminosilicate dissolution. Correlation of $\mathrm{Zn}, \mathrm{Pb}$ and $\mathrm{Ni}$ indicates coprecipitation/sorption with secondary iron (oxide-) hydroxides. 


\section{Discussion}

The studied sequence corresponds to a fining-upwards array of multi-story sand bodies with intercalated coal seams. According to Becker et al. [30,37], the short horizontal gradation of the sandstones is a consequence of a braided to meandering fluvial environment. This does not modify the mineralogical composition of the rocks but their proportions.

Based on the distribution of mineral transformations, two types of water-rock interaction are distinguished. On one hand, kaolinite, dickite, illite and sericite are present in all the analyzed sections, being related to similar alteration processes over the whole Westfield. On the other hand, iron (oxide-) hydroxides display variable spatial distribution at large scale, being linked to weathering processes near fracture elements. Considering the poor hydraulic properties of the rocks, mineral arrangements may also allow discrimination between diagenetic alteration processes and "recent" weathering events.

\subsection{Kaolinite, Dickite, Illite and Sericite Formation}

Relatively constant amounts of kaolinite, dickite, illite and sericite were found in the samples of both drill cores. Mineral habits suggest their formation from alteration processes of feldspars and lithic grains. However, no significant difference was recognized on their distribution between weathered reddish zones and grayish pristine rock sections. Therefore, water-rock interaction under the current conditions of the area had little influence on the rock matrix.

Feldspar kaolinitization occurs in areas with humid and mild climates, constantly flushed with meteoric or low-pH waters [43]. Even though these conditions existed in the studied area, low permeability of shales, coal and tight sandstones provide a sufficient seal against regional weathering. Bässler [34], for example, estimated permeabilities below 1 millidarcy $(\mathrm{mD})$ for shallow coal roof sandstones in Ibbenbüren. In addition, Becker et al. [30] used more than 30 sandstone samples from the Woitzel quarry (see Figure 1) to calculate an average permeability of $0.05 \mathrm{mD}$ at confining pressures of $1 \mathrm{MPa}(\approx 30 \mathrm{~m}$ depth). From these low values, it is highly unlikely that recent water-rock interaction generates the widespread distribution of kaolinite in the overburden. Feldspar kaolinitization could then occurred during an early diagenetic stage. According to Wüstefeld et al. [31], a warm climate controlled the Eodiagenesis of the German northwestern Carboniferous sequence. During this stage, mechanical compaction reorganized most of the feldspar fragments into the pore spaces, letting them interact with the rock fluids. This interaction resulted in grain dissolution with subsequent kaolinite precipitation. Nowadays, feldspar kaolinitization is irrelevant due to the low proportion of remaining feldspars.

In addition to kaolinite, dickite was identified in the sandstone matrix. "Dickitization" has been reported at temperatures above $130{ }^{\circ} \mathrm{C}$ at a depth of approximately $3.2 \mathrm{~km}$ in the Norwegian shelf [44]. Similarly, the transformation of kaolinite to dickite has been prescribed to depths below $3.3 \mathrm{~km}$ by Beaufort et al. [45], linking this formation to the time of deep burial.

Illite appears as a secondary phase mainly formed from the alteration of kaolinite and dickite. Time, pressure, pore fluid composition and hydrothermal activity are important factors in the mineral formation [46,47]. Illitization is a diagenetic process that takes place over long timespans, at intermediate burial depth, with temperatures and pressures around $100{ }^{\circ} \mathrm{C}$ and $100 \mathrm{MPa}$ ( $>3 \mathrm{~km}$ depth) [30,48,49]. Since samples only cover the first $80 \mathrm{~m}$ of the shallowest overburden, illitization had to happen probably during the mesogenetic realm, when the deep burial of the sedimentary sequence began [31,50]. A similar explanation is proposed for sericite formation, which requires the rock to interact with moderately acidic fluids at high temperatures, usually associated with deep burial conditions [51]. Under such conditions, water is tightly bound to the primary porosity. Ions that are liberated from the primary minerals diffuse slowly and migrate over short distances before being incorporated into the secondary minerals.

The preservation of kaolinite and dickite alongside illite may point to the limited availability of potassium-bearing solutions in the Ibbenbüren sandstones [49]. However, 
the transformation of kaolinite into dickite through a coupled dissolution-precipitation process suggests that pore waters were available when the relevant temperatures for illitization were present [44]. In addition, potassium-rich pore waters have been reported within the carboniferous sandstones from the Ibbenbüren coalfield [10]. Considering that dickite is a thermodynamically stable mineral in a range of environmental conditions [52], a kinetic control due to a relatively short timespan at depths with relevant pressure and temperature could explain the coexistence of kaolinite and dickite. Similarly, this could also explain the incomplete illitization of both mineral phases.

Interestingly, the partial illitization of kaolinite observed in the samples would show a different burial record from that described in Becker et al. [30]. Here, the author separated the diagenetic history of the Ibbenbüren Carboniferous block from that of Hüggel and Piesberg based on the complete replacement of illite during the earliest burial phase. Again, this points to the relatively strong heterogeneity of sandstone reservoirs at small scales, which make the extrapolation of core logging a challenging process.

\section{2. (Oxide-) Hydroxide Formation}

The lower Westphalian D sequence has been interpreted to be deposited under humid conditions, with almost no presence of opaque or iron oxide minerals [53]. This feature is contrary to the relatively high percentage of (oxide-) hydroxides encountered in fractured intervals. However, deposits of weathering origin can be distinguished from those of detrital origin by careful observation of thin sections. Iron (oxide-) hydroxides that originate from transport as solutions show a tendency to nucleate and grow perpendicular to the walls of the pore system, whereas those that come from the transport of detrital material exhibit a tendency to be layered or deposited among the frame minerals of the rock [54].

Within the thin section, iron (oxide-) hydroxides show perpendicular growing around the pore walls. Their development in the fracture vicinity rules out a regional oxidative process during the diagenesis, whilst their absence in unfractured samples discards a syndepositional origin. Thus, local weathering of Fe-bearing minerals prompted by fractures may be the origin of the iron (oxide-) hydroxides in the area. This can be evidenced, for example, from the alteration state of pyrite clusters. While fresh brass-yellow pyrite appears in complete core samples, holopseudomorphism and pellicular rims of (oxide-) hydroxides are developed around the crystals of the fractured segments.

\subsubsection{Fe Source in the Rocks}

Pyrite is the only Fe-bearing reactive mineral identified in the rock samples. The mineral occurs as clusters of microcrystals usually associated with sedimentary lithic fragments and rarely as frame macro-crystals. Development of microcrystals represents higher reactive surface areas, which is a key parameter for the oxidation rate [55]. Moreover, fine-grained marcasite and pyrite crystals are expected to be present in lenses and coal fragments within the sandstones. This consideration is supported by Lotze et al. [23], who blamed the high pyrite content in some coal seams as one of the elements in charge of generating mineralized drainage in the Ibbenbüren Westfield.

\subsubsection{Influence of Fractures in the Oxidation-Precipitation System of the Westfield}

Fractures may strongly influence the water-rock interaction in the tight Carboniferous sequence. These structures broadly segment core samples into several pieces, developing weathering fronts at both sides of their planes. Contrarily, joints develop black oxide cements on their surface, leaving almost no open spaces for water to flow. Although the exact nature of fractures is unknown, some are expected to be related to former mining activities. The absence of healing elements (as occurred with the joints) and the partial alteration of rock volumes around them, may be interpreted as indicators of their recent origin.

Underground coal mining operations tend to change the stress state of the rocks, generating horizontal and sub-vertical fracture networks above and below the mined seams [28]. This bidirectional distribution creates a highly permeable zone that dominates the global 
vertical water flow [28]. Locally, fluid can be horizontally exchanged between fractures and porous rocks by pressure and chemical differences [56]. As a result, water propagates rapidly through the fractures, while slowly invading the tight matrix blocks [57-60]. In such a system water can interact with iron-bearing minerals within the overburden. Oxidized pyrite and iron (oxide-) hydroxides in weathering profiles along both sides of the macro-fractures are the result of this interaction. Thus, when meteoric (oxygenated) water flows from the fracture into the sandstones, pyrite oxidation would proceed according to Reaction (1) [61]:

$$
\mathrm{FeS}_{2}(s)+7 / 2 \mathrm{O}_{2}(g)+\mathrm{H}_{2} \mathrm{O} \rightarrow \mathrm{Fe}_{(a q)}^{2+}+2 \mathrm{SO}_{4}^{2-}(a q)+2 \mathrm{H}_{(a q)}^{+}
$$

This process additionally releases trace elements included within the mineral lattice (e.g., Se, As, Cd and Zn). Alternatively, oxidation can proceed according to the following reaction:

$$
\mathrm{FeS}_{2(s)}+14 \mathrm{Fe}_{(a q)}^{3+}+8 \mathrm{H}_{2} \mathrm{O} \rightarrow 15 \mathrm{Fe}_{(a q)}^{2+}+2 \mathrm{SO}_{4}{ }_{(a q)}^{2-}+16 \mathrm{H}_{(a q)}^{+}
$$

After pyrite oxidizes, amorphous iron (oxide-) hydroxides can be formed through the oxidation of $\mathrm{Fe}_{(a q)}^{2+}$ to $F e_{(a q)}^{3+}$ (Reaction (3)). Subsequently, $F e_{(a q)}^{3+}$ can either precipitate as goethite, which is the themodynamic stable phase at $\mathrm{pH}$ values $2.5-5.5$ (Reaction (4)), or as ferrihydrite, stable at $\mathrm{pH}$ values $>5.5$ (Reaction (5)) [61]:

$$
\begin{gathered}
\mathrm{Fe}_{(a q)}^{2+}+1 / 4 \mathrm{O}_{2}{ }_{(g)}+\mathrm{H}^{+}{ }_{(a q)} \rightarrow \mathrm{Fe}_{(a q)}^{3+}+1 / 2 \mathrm{H}_{2} \mathrm{O} \\
\mathrm{Fe}^{3+}{ }_{(a q)}+2 \mathrm{H}_{2} \mathrm{O} \rightarrow \mathrm{FeOOH}{ }_{(\text {goethite })}+3 \mathrm{H}^{+}{ }_{(a q)} \\
\mathrm{Fe}^{3+}{ }_{(a q)}+3 \mathrm{H}_{2} \mathrm{O} \rightarrow \mathrm{Fe}(\mathrm{OH})_{(\mathrm{s})}+3 \mathrm{H}^{+}{ }_{(a q)}
\end{gathered}
$$

For deep unsaturated zones, Reactions (3) to (5) would be limited by the small amount of oxygen left by pyrite oxidation (Reaction (1)). As a result, $\left.\mathrm{Fe}_{(a q)}^{2+}\right)^{2+} \mathrm{SO}_{4(a q)}^{2-}$ and $\mathrm{H}_{(a q)}^{+}$are released to the fractures when water potential is high in the porous medium (reverse flow). It is also expected that ion freight decreases over time due to pore clogging and grain coating by iron (oxide-) hydroxides. In the end, the whole oxidation-precipitation process is repeated for each rainy event, which replenishes the dissolved oxygen in the medium.

However, the observed features in the weathering profiles along both sides of fractures are not enough to generate the high iron and sulfate content of the discharge water. The textural fluctuations between core samples together with the variable percentages of reactive components among layers (pyrite and coal particles) generate a significant uncertainty. For instance, the relatively high total iron content in weathered samples is not balanced by pyrite-bound iron in the unweathered samples. This points either to the migration and transport of fluid through larger distances within the porous medium (i.e., the outflow of formation water from the porous sandstones after the induction of fractures) or to the origin of those elements from outside of the sampled sandstones. In the latter case, origin of iron-rich waters, infiltrated from the previous Permian (Zechstein) cover, would be a possible source. However, no evidence of Permian influence on formation waters was found in the deep Ibbenbüren mine [10]. Either way, it is unlikely that modern interaction between percolating rain water and the evaluated rock section in this study is the primary source of the dissolved iron and sulfate in the mine drainage. This in turn points to the heterogeneity within the overburden, with large amounts of pyrite in localized areas and/or the dissolution of secondary sulfur-bearing minerals from the mine shafts [62].

\section{Conclusions}

Traces of water-rock interaction were assigned to two different categories. Illite, kaolinite and dickite are evenly distributed among the matrix of the weathered and unweathered rock zones and are related to the diagenesis history of the area. On the other hand, the 
presence of iron (oxide-) hydroxides along the fractures is linked to the dissolution of pyrite. However, relatively high iron contents in the weathered zone face relatively low pyrite contents in the unweathered rocks. The low porosity and permeability of the analyzed samples exclude deep percolation of infiltrated rainwater into the rocks. Accordingly, the high contents of iron (oxide-) hydroxides may be the result of outflowing formation water, within a relatively short timespan after the opening of the fractures. Alternatively, pyrite dissolution from outside of the analyzed core samples is also possible. The latter points to the heterogeneity observed within the sedimentary sequence and the challenge of upscaling observations from drill cores to complete rock sequences.

Supplementary Materials: The following are available online at https: / www.mdpi.com/article / 10.3390/min11050483/s1, Table S1: The chemical composition of the selected rock samples.

Author Contributions: Conceptualization, D.B.-G. and T.R.; methodology, D.B.-G. and T.R.; investigation, D.B.-G., T.R and G.R.; writing—original draft preparation, D.B.-G. and T.R.; writing-review and editing, D.B.-G., T.R. and S.H.; funding acquisition, S.H. All authors have read and agreed to the published version of the manuscript.

Funding: This work was financially supported by the Forum Bergbau und Wasser-FBW.

Acknowledgments: The authors would like to thank Manfred Bernroider for assistance with the petrographic investigation. Bastian Nippert (from Spang Ingenieurgesellschaft für Bauwesen, Geologie und Umwelttechnik $\mathrm{mbH}$ ) is thanked for providing the core samples for the studied area. Natasa Ostermann is thanked for her help in the preparation of the thin sections. The authors would also like to acknowledge the facilities and the scientific assistance of the staff at the Department of Chemistry and Physics of Materials at the University of Salzburg, especially David Schiller and Fritz Finger for RFA Analyses and Gregor Zickler for his help with the SEM. We thank everybody from RAG Anthrazit Ibbenbüren for facilitating sampling and providing important insights into mine details. The academic editors and three anonymous reviewers are thanked for their help to improve this manuscript.

Conflicts of Interest: The authors declare that they have no known competing financial interests or personal relationships that could have appeared to influence the work reported in this paper.

\section{References}

1. Kretschmann, J. Post-Mining-A Holistic Approach. Min. Metall. Explor. 2020, 37, 1401-1409. [CrossRef]

2. Kretschmann, J. Sustainability-orientated post-mining in Germany. Eurasian Min. 2017, 33-38. [CrossRef]

3. Oei, P.Y.; Brauers, H.; Herpich, P. Lessons from Germany's hard coal mining phase-out: Policies and transition from 1950 to 2018. Clim. Policy 2020, 20, 963-979. [CrossRef]

4. Kretschmann, J.; Efremenkov, A.B.; Khoreshok, A.A. From Mining to Post-Mining: The Sustainable Development Strategy of the German Hard Coal Mining Industry. IOP Conf. Ser. Earth Environ. Sci. 2017, 50, 012024. [CrossRef]

5. Kessler, T.; Mugova, E.; Jasnowski-Peters, H.; Rinder, T.; Stemke, M.; Wolkersdorfer, C.; Hilberg, S.; Melchers, C.; Struckmeier, W.; Wieber, G.; et al. Grundwasser in ehemaligen deutschen Steinkohlenrevieren-Ein wissenschaftlicher Blickwinkel auf Grubenflutungen. Grundwasser 2020, 25, 259-272. [CrossRef]

6. Cravotta, C.A. Dissolved metals and associated constituents in abandoned coal-mine discharges, Pennsylvania, USA. Part 1: Constituent quantities and correlations. Appl. Geochem. 2008, 23, 166-202. [CrossRef]

7. Cravotta, C.A.; Brady, K. Priority pollutants and associated constituents in untreated and treated discharges from coal mining or processing facilities in Pennsylvania, USA. Appl. Geochem. 2015, 62, 108-130. [CrossRef]

8. Morin, K.A.; Hutt, N.M. Environmental Geochemistry of Minesite Drainage: Practical Theory and Case Studies; MDAG Publishing: Vancouver, BC, Canada, 2001; ISBN 0968203914.

9. Nordstrom, D.K. Mine waters: Acidic to circumneutral. Elements 2011, 7, 393-398. [CrossRef]

10. Rinder, T.; Dietzel, M.; Stammeier, J.A.; Leis, A.; Bedoya-González, D.; Hilberg, S. Geochemistry of coal mine drainage, groundwater, and brines from the Ibbenbüren mine, Germany: A coupled elemental-isotopic approach. Appl. Geochem. 2020, 121, 104693. [CrossRef]

11. Wolkersdorfer, C.; Bowell, R. Contemporary reviews of mine water studies in Europe, Part. Mine Water Environ. 2004, 23, 162-182. [CrossRef]

12. Younger, P.L.; Wolkerdorfer, C.H.; Bowell, R.J.; Diels, L. Partnership for acid drainage remediation in Europe (PADRE): Building a better future founded on research and best practice. In Proceedings of the 7th International Conference on Acid Rock Drainage (ICARD), St. Louis, MO, USA, 26-30 March 2006; American Society of Mining and Reclamation: Lexington, KY, USA, 2006; Volume 3, pp. 2571-2574. [CrossRef] 
13. Gombert, P.; Sracek, O.; Koukouzas, N.; Gzyl, G.; Valladares, S.T.; Frączek, R.; Klinger, C.; Bauerek, A.; Areces, J.E.Á.; Chamberlain, S.; et al. An Overview of Priority Pollutants in Selected Coal Mine Discharges in Europe. Mine Water Environ. 2018, $38,16-23$. [CrossRef]

14. Johnson, D.B.; Hallberg, K.B. Acid mine drainage remediation options: A review. Sci. Total Environ. 2005, 338, 3-14. [CrossRef] [PubMed]

15. Qureshi, A.; Maurice, C.; Öhlander, B. Potential of coal mine waste rock for generating acid mine drainage. J. Geochem. Explor. 2016, 160, 44-54. [CrossRef]

16. Johnson, D.B. Chemical and microbiological characteristics of mineral spoils and drainage waters at abandoned coal and metal mines. Water Air Soil Pollut. Focus 2003, 3, 47-66. [CrossRef]

17. $\mathrm{Xu}$, T.; White, S.P.; Pruess, K.; Brimhall, G.H. Modeling of pyrite oxidation in saturated and unsaturated subsurface flow systems. Transp. Porous Media 2000, 39, 25-56. [CrossRef]

18. Banks, D.; Younger, P.L.; Arnesen, R.T.; Iversen, E.R.; Banks, S.B. Mine-water chemistry: The good, the bad and the ugly. Environ. Geol. 1997, 32, 157-174. [CrossRef]

19. Blowes, D.W.; Ptacek, C.J.; Jambor, J.L.; Weisener, C.G. The Geochemistry of Acid Mine Drainage. Treatise Geochem. 2003, 9 , 149-204.

20. Akcil, A.; Koldas, S. Acid Mine Drainage (AMD): Causes, treatment and case studies. J. Clean. Prod. 2006, 14, 1139-1145. [CrossRef]

21. Younger, P.L.; Robins, N.S. Challenges in the Characterization and Prediction of the Hydrogeology and Geochemistry of Mined Ground; Special Publications; Geological Society of London: London, UK, 2002; Volume 198, pp. 1-16. [CrossRef]

22. DMT GmbH \& Co. KG. Abschlussbetriebsplan des Steinkohlenbergwerks Ibbenbüren Anlage 17-Prognose zur optimierten Wasserannahme nach Stilllegung des Steinkohlenbergwerkes Ibbenbüren (Ostfeld); RAG Anthrazit Ibbenbüren GmbH: Essen, Germany, 2019; 104p.

23. Lotze, F.; Semmler, W.; Kötter, K.; Mausolf, F. Hydrogeologie des Westteils der Ibbenbürener Karbonscholle; Springer Fachmedien Wiesbaden GmbH.: Wiesbaden, Germany, 1962; ISBN 9783663006657.

24. David, K.; Timms, W.A.; Barbour, S.L.; Mitra, R. Tracking changes in the specific storage of overburden rock during longwall coal mining. J. Hydrol. 2017, 553, 304-320. [CrossRef]

25. Liu, Y.; Liu, Q.M.; Li, W.P.; Li, T.; He, J.H. Height of water-conducting fractured zone in coal mining in the soil-rock composite structure overburdens. Environ. Earth Sci. 2019, 78, 242-255. [CrossRef]

26. Majdi, A.; Hassani, F.P.; Nasiri, M.Y. Prediction of the height of destressed zone above the mined panel roof in longwall coal mining. Int. J. Coal Geol. 2012, 98, 62-72. [CrossRef]

27. Qu, Q.; Xu, J.; Wu, R.; Qin, W.; Hu, G. Three-zone characterisation of coupled strata and gas behaviour in multi-seam mining. Int. J. Rock Mech. Min. Sci. 2015, 78, 91-98. [CrossRef]

28. Zhang, X.; Ghabraie, B.; Ren, G.; Tu, M. Strata movement and fracture propagation characteristics due to sequential extraction of multiseam longwall panels. Adv. Civ. Eng. 2018. [CrossRef]

29. Newman, C.; Agioutantis, Z.; Boede Jimenez Leon, G. Assessment of potential impacts to surface and subsurface water bodies due to longwall mining. Int. J. Min. Sci. Technol. 2017, 27, 57-64. [CrossRef]

30. Becker, I.; Wüstefeld, P.; Koehrer, B.; Felder, M.; Hilgers, C. Porosity and permeability variations in a tight gas sandstone reservoir analogue, Westphalian D, Lower Saxony basin, NW Germany: Influence of depositional setting and diagenisis. J. Pet. Geol. 2017, 40, 363-389. [CrossRef]

31. Wüstefeld, P.; Hilse, U.; Koehrer, B.; Adelmann, D.; Hilgers, C. Critical evaluation of an Upper Carboniferous tight gas sandstone reservoir analog: Diagenesis and petrophysical aspects. Mar. Pet. Geol. 2017, 86, 689-710. [CrossRef]

32. Drozdzewski, G.; Dölling, M. Elemente der Osning-Störungszone (NW-Deutschland)—Leitstrukturen einer Blattverschiebungszone. In Scriptum online 7; Geologischer Dienst Nordrhein-Westfalen: Krefeld, Germany, 2018.

33. Bruns, B.; Littke, R. Lithological dependency and anisotropy of vitrinite reflectance in high rank sedimentary rocks of the Ibbenbüren area, NW-Germany: Implications for the tectonic and thermal evolution of the Lower Saxony Basin. Int. J. Coal Geol. 2015, 137, 124-135. [CrossRef]

34. Bässler, R. Hydrogeologische, chemische und Isotopen-Untersuchungen der Grubenwässer im Ibbenbürener Steinkohlenrevier. Z. Deutsch. Geol. Ges. 1970, 209-286. [CrossRef]

35. Coldewey, W.G.; Wesche, D. Hydrologie und Hydrogeologie der Ibbenbürener Karbon-Scholle. In Scriptum Online 14; Geologischer Dienst Nordrhein-Westfalen: Krefeld, Germany, 2020; pp. 1-10. Available online: https://www.gd.nrw.de/zip/ scriptumonline-14_2020-07.pdf (accessed on 28 April 2021).

36. Bundesamt für Kartographie und Geodäsie, (BKG). Shapefile of Administrative Boundaries (WGS84). 2011. Available online: https://www.zensus2011.de/EN/Media/Background_material/Background_material_node.html (accessed on 23 April 2021).

37. Becker, I.; Busch, B.; Koehrer, B.; Adelmann, D.; Hilgers, C. Reservoir Quality Evolution of Upper Carboniferous (Westphalian) Tight Gas Sandstones, Lower Saxony Basin, Nw Germany. J. Pet. Geol. 2019, 42, 371-392. [CrossRef]

38. Rudakov, D.V.; Coldewey, W.G.; Goerke-Mallet, P. Modeling the Inflow and Discharge from Underground Structures within the Abandoned Hardcoal Mining Area of West Field (Ibbenbüren). In An Interdisciplinary Response to Mine Water Challenges, Proceedings of the 12th International Mine Water Association Congress (IMWA), Xuzhou, China, 18-22 August 2014; Sui, W., Sun, Y., Wang, C., Eds.; China University of Mining and Technology: Xuzhou, China, 2014; pp. 699-705. 
39. Drozdzewski, G. Tiefentektonik der Ibbenbürener Karbon-Scholle. In Beiträge zur Tiefentektonik westdeutscher Steinkohlenlagerstätten; Geologisches Landesamt Nordrhein Krefeld: Krefeld, Germany, 1985; pp. 189-216.

40. Ingersoll, R.V.; Bullard, T.F.; Ford, R.L.; Grimm, J.P.; Pickle, J.D.; Sares, S.W. The effect of grain size on detrital modes: A test of the Gazzi- Dickinson point-counting method (Holocene, sand, New Mexico, USA). J. Sediment. Petrol. 1984, 54, $103-116$.

41. Bertier, P.; Swennen, R.; Lagrou, D.; Laenen, B.E.N.; Kemps, R. Palaeo-climate controlled diagenesis of the Westphalian C \& D fluvial sandstones in the Campine Basin (north-east Belgium). Sedimentology 2008, 55, 1375-1417.

42. Nagy, K.L.; Blum, A.E.; Lasaga, A.C. Kaolinite precipitation and dissolution: Effects on porosity and permeability. Am. Assoc. Pet. Geol. Bull. 1989, 73.

43. Pierini, C.; Mizusaki, A.M.P.; Scherer, C.M.S.; Alves, D.B. Integrated stratigra phic and geochemical study of the Santa Maria and Caturrita formations (Triassic of the Paraná Basin), southern Brazil. J. S. Am. Earth Sci. 2002, 15, 669-681. [CrossRef]

44. Ehrenberg, S.N.; Aagaard, P.; Wilson, M.J.; Fraser, A.R.; Duthie, D.M.L. Depth-Dependent Transformation of Kaolinite to Dickite In Sandstones of the Norwegian Continental Shelf. Clay Miner. 1993, 28, 325-352. [CrossRef]

45. Beaufort, D.; Cassagnabere, A.; Petit, S.; Lanson, B.; Berger, G.; Lacharpagne, J.C.; Johansen, H. Kaolinite-to-dickite reaction in sandstone reservoirs. Clay Miner. 1998, 33, 297-316. [CrossRef]

46. Huggett, J.M. Clays and Their Diagenesis. In Encyclopedia of Geology; Selley, R.C., Cocks, L.R., Plimer, I., Eds.; Elsevier Ltd.: London, UK, 2005; pp. 62-70.

47. Huang, W. The Formation of Illitic Clays from Kaolinite in $\mathrm{KOH}$ Solution from $225^{\circ} \mathrm{C}$ to $350{ }^{\circ} \mathrm{C}$. Clays Clay Miner. 1993, 41 , 645-654.

48. Mantovani, M.; Becerro, A.I. Illitization of kaolinite: The effect of pressure on the reaction rate. Clays Clay Miner. 2010, 58, 766-771. [CrossRef]

49. Thyne, G.; Boudreau, B.P.; Ramm, M.; Midtbø, R.E. Simulation of potassium feldspar dissolution and illitization in the Statfjord Formation, North Sea. Am. Assoc. Pet. Geol. Bull. 2001, 85, 621-635. [CrossRef]

50. Galán, E.; Ferrell, R.E. Genesis of Clay Minerals; Developments in Clay Science, Elsevier Ltd.: Oxford, UK, 2013; Volume 5, pp. 83-126. ISBN 9780080982588. [CrossRef]

51. Que, M.; Allen, A.R. Sericitization of plagioclase in the Rosses Granite Complex, Co. Donegal, Ireland. Mineral. Mag. 1996, 60, 927-936. [CrossRef]

52. Zotov, A.; Mukhamet-Galeev, A.; Schott, J. An experimental study of kaolinite and dickite relative stability at 150-300 degrees C and the thermodynamic properties of dickite. Am. Mineral. 1998, 83, 516-524. [CrossRef]

53. Besly, B.M.; Burley, S.D.; Turner, P. The late Carboniferous "Barren Red Bed" play of the Silver Pit area, southern north sea. Pet. Geol. Conf. Proc. 1993, 4, 727-740. [CrossRef]

54. Delvigne, J.E. Atlas of Micromorphology of Mineral Alteration and Weathering; Special Publication; Martin, R.F., Ed.; Mineralogical Association of Canada: Quebec City, QC, Canada, 1998; ISBN 0921294433.

55. Chandra, A.P.; Gerson, A.R. The mechanisms of pyrite oxidation and leaching: A fundamental perspective. Surf. Sci. Rep. 2010, 65, 293-315. [CrossRef]

56. Pruess, K.; Narasimhan, T.N. A practical method for modeling fluid and heat flow in fractured porous media. Soc. Pet. Eng. J. 1985, 25, 14-26. [CrossRef]

57. Hao, Y.; Fu, P.; Carrigan, C.R. Application of a dual-continuum model for simulation of fluid flow and heat transfer in fractured geothermal reservoirs. In Proceedings of the 38th Workshop on Geothermal Reservoir Engineering; SGP-TR-198; Stanford University: Stanford, CA, USA, 2013; pp. 462-469.

58. Kordilla, J.; Sauter, M.; Reimann, T.; Geyer, T. Simulation of saturated and unsaturated flow in karst systems at catchment scale using a double continuum approach. Hydrol. Earth Syst. Sci. 2012, 16, 3909-3923. [CrossRef]

59. Kovács, A.; Sauter, M. Modelling karst hydrodynamics. In Methods in Karst Hydrogeology; Goldscheider, N., Drew, D., Eds.; Taylor \& Francis: London, UK, 2007; pp. 201-222. ISBN 6087858393.

60. Sauter, M. Quantificaton and Forecasting of Regional Groundwater Flow and Transport in a Karst Aquifer (Gallusquelle, Malm, SW. Germany); Geowissenschaftliche Fakultät: Jena, Germany, 1992.

61. Nordstrom, D.K.; Blowes, D.W.; Ptacek, C.J. Hydrogeochemistry and microbiology of mine drainage: An update. Appl. Geochem. 2015, 57, 3-16. [CrossRef]

62. Hammarstrom, J.M.; Seal, R.R.; Meier, A.L.; Kornfeld, J.M. Secondary sulfate minerals associated with acid drainage in the eastern US: Recycling of metals and acidity in surficial environments. Chem. Geol. 2005, 215, 407-431. [CrossRef] 